\title{
Immunomagnetic Column
}

National Cancer Institute

\section{Source}

National Cancer Institute. Immunomagnetic Column. NCI Thesaurus. Code C71606.

A separation column that when placed in proximity to a magnet creates a high gradient magnetic field strong enough to retain cells labeled with antibodies complexed to magnetic particles. 